\title{
RELIABILITY OF A SIMPLE NOVEL FIELD TEST FOR THE MEASUREMENT OF PLANTAR FLEXOR MUSCLE STRENGTH
}

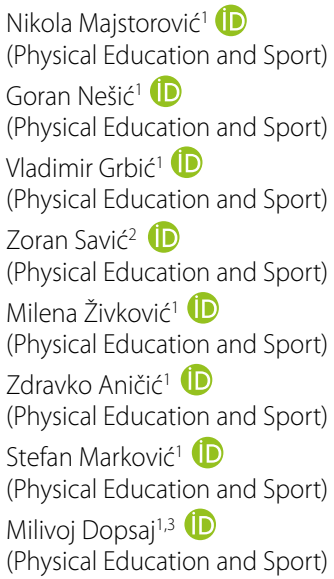

1. Belgrade University, Faculty of Sport and Physical Education, Belgrade, Serbia.

2. Pristina University, Faculty of Sport and Physical Education, Leposavić, Serbia.

3. South Ural State University, Institute of Sport, Tourism and Service, Chelyabinsk, Russia.

\section{Correspondence:}

Nikola Majstorović. Faculty of Sport and Physical Education. Blagoja Parovića, 156, Belgrade, Serbia. nikola.majstorovic@fsfv.bg.ac.rs

\begin{abstract}
Introduction: When a person is in a standing position, the plantar flexor muscles are involved in most static and dynamic body movements. Objectives: The aim of this study was to investigate the trial to trial and factorial reliability of measuring the contractile characteristics of PF muscles using a simple novel field test. Methods: The sample consisted of 452 healthy subjects, 120 male and 332 female. The research was conducted by means of the trial to trial testing method, using isometric dynamometry performed in field conditions. ANOVA was used to estimate the differences among the trials, Cronbach's alpha and interclass correlation to estimate the correlations among the trials, and principal component analysis to evaluate the contribution of each trial to overall variability. Results: The main findings of this study are that trials differed significantly $(p<0.000)$ for maximal force $\left(F_{\max }\right)$ and maximal rate of force development $\left(\mathrm{RFD}_{\max }\right)$, indicating that the three procedural trials were necessary. The trials were highly correlated $\left(F_{\max }, R F D_{\max }, r>0.9\right)$, proving that measuring was reliable, and the factorial analysis separated the second and third trials, the second trial accounting for most of the total variability. Conclusions: The simple novel field test for the measurement of plantar flexor contractile characteristics recommended by this study proved to be as highly reliable as laboratory testing, but was easy to perform in conditions outside of scientific or diagnostic institutions, which greatly facilitates the work of scientists, coaches and professionals. Level of Evidence Il; Diagnostic Studies - Investigating a diagnostics test.
\end{abstract}

Keywords: Muscle strength; Dynamometer; Gastrocnemius; Soleus.

\section{RESUMO}

Introdução: Quando uma pessoa está em pé, os músculos flexores plantares são envolvidos na maioria dos movimentos corporais estáticos e dinâmicos. Objetivos: O objetivo deste estudo foi investigar a confiabilidade teste-retestee fatorial da mensuração das características contráteis dos músculos plantares, usando um novo teste de campo simples. Métodos: A amostra consistiu em 452 individuos saudáveis, 120 homens e 332 mulheres. O estudo foi realizado pelo método de teste-reteste, com dinamometria isométrica conduzida em condições de campo. Empregou-se a ANOVA para estimar a diferença entre os testes o alfa de Cronbach e a correlação interclasse para estimar a correlação entre os testes e análise de componentes principais, para avaliar a contribuição de cada teste para a variabilidade global. Resultados: Os principais achados deste estudo são que os testes diferiram significativamente $(p<0,000)$ para a força máxima $\left(F_{\text {máx }}\right)$ e a taxa máxima de desenvolvimento de força (TDF maxx) indicando que os três testes de procedimento foram necessários. Os testes foram altamente correlacionados ( $\left.F_{\text {máx }} T D F_{\text {máx }} r>0,9\right)$, provando que a medição era confiável, e a análise fatorial separou o segundo e o terceiro testes, sendo que o segundo teste apresentou a maior parte da variabilidade total. Conclusões: O novo teste de campo simples para medição das características contráteis dos flexores plantares recomendado por este estudo provou ser tão confiável quanto os testes de laboratório e, ao mesmo tempo, mais fácil de realizar fora das instituições cientificas ou de diagnóstico, o que facilita muito o trabalho de cientistas, treinadores e profissionais. Nível de Evidência ll; Estudos Diagnósticos - Investigação de um exame para diagnóstico.

Descritores: Força muscular; Dinamómetro; Gastrocnemio; Soleus.

\section{RESUMEN}

Introducción: Cuando una persona está de pie, los músculos flexores plantares son involucrados en la mayoría de los movimientos corporales estáticos y dinámicos. Objetivos: El objetivo de este estudio fue investigar la confiabilidad test-retest y factorial de la medición de las características contráctiles de los músculos plantares, usando un nuevo test de campo simple. Métodos: La muestra consistió en 452 individuos saludables, 120 hombres y 332 mujeres. El estudio fue realizado a través del método de test-retest, con dinamometría isométrica conducida en condiciones de campo. Se empleó ANOVA para estimar la diferencia entre los tests, alpha de Crombach y la correlación interclase para estimar la correlación entre los tests y el análisis de componentes principales, para evaluar la contribución de cada test para la variabilidad global. Resultados: Los principales hallazgos de este estudio son que los tests difirieron significativamente $(p<0,000)$ para la fuerza 
máxima $\left(F_{\text {máx }}\right)$ y la tasa máxima de desarrollo de fuerza $\left(T D F_{\text {máx }}\right)$ indicando que los tres tests de procedimiento fueron necesarios. Los tests fueron altamente correlacionados $\left(F_{\text {máx }} T D F_{\text {máx }} r>0,9\right)$ probando que la medición era confiable, y el análisis factorial separó el segundo y tercer test, siendo que el segundo test presentó la mayor parte de variabilidad total. Conclusiones: El nuevo test de campo simple para medición de las características contráctiles de los flexores plantares recomendado por este estudio probó ser tan confiable como los tests de laboratorio y, al mismo tiempo, más fácil de realizar fuera de las instituciones científicas o de diagnóstico, lo que facilita mucho el trabajo de científicos, entrenadores y profesionales. Nivel de evidencia ll; Estudios diagnósticos - Investigación de un examen para diagnóstico.

Descriptores: Fuerza muscular; Dinamômetro; Gastrocnêmio; Soleus.

\section{INTRODUCTION}

Ankle joint muscles are one of the most important muscles for maintaining balance and standing position. ${ }^{1}$ These muscles also have an important function in locomotion, i.e. in large number of dynamic movements that human body can perform as a part of the demands in everyday activities, as well as in sports activities. ${ }^{2,3}$

The results of strength testing of PF muscles can provide useful information about the athletes conditioning status, therefore monitoring should be of great importance in every athlete's training regime, especially in sports based on jumps and agility performance. The criterion-reference assessment of muscle strength and power involves fixed laboratory based dynamometry. ${ }^{1,4} \mathrm{~A}$ limitation of laboratory-based dynamometers is that they are expensive and cumbersome, which precludes their use as a device for routine assessment. ${ }^{5}$ Additionaly, injured athletes, or rehabilitation patients could have serious difficulties visiting a laboratory in order to follow their rehabilitation processes. All of the earlier mentioned reasons indicate that PF muscles contractile characteristics measurement should be made available to athletes and their coaches, as well as rehabilitation patients and clinicians, for periodic monitoring during the sports season, or efficiency of injury rehabilitation. This kind of frequent testing implies simple procedures, instruments which are not too expensive, and can be easily used in the conditions other than the laboratory. These procedures must be evaluated ${ }_{1}^{6,7}$ and their measurement characteristics described ${ }^{8}$ before recommending them for practical application as a suitable instrument for performance assessment. The aim of this study was to investigate trail to trail, and factorial reliability of PF muscles contractile characteristics using a simple novel field test.

\section{MATERIALS AND METHODS}

The research is conducted by trial to trial testing method, using isometric dynamometry performed in field conditions. The study was conducted in accordance with the Declaration of Helsinki and approved by the Ethics committee of the Faculty of Sports and Physical Education, University in Belgrade (02 No.484-2). All participants were informed about the aim and course of the study, and they agreed to the presented conditions in written form.

Sample consisted of 452 subjects, 120 male and 332 female subjects. All subjects were healthy young adults, with no injuries that could influence the results of this study. Basic descriptive characteristics of the subject sample were: males age $=26.4 \pm 2.8 \mathrm{yrs}$., body height $=182.6 \pm 11.2 \mathrm{~cm}$, body mass $=79.2 \pm 13.3 \mathrm{~kg}, \mathrm{BMl}=23.74 \pm 2.01 \mathrm{~kg} / \mathrm{m}^{2}$; females age $=24.8 \pm 2.8$, body height $=174.7 \pm 7.9 \mathrm{~cm}$, body mass $=66.9 \pm 8.7 \mathrm{~kg}, \mathrm{BMl}=21.92 \pm 2.28 \mathrm{~kg} / \mathrm{m}^{2}$.

\section{Testing procedure}

Body height and body mass were assessed by a standard anthropometer (GPM, Swis Made, Zurich, Switzerland) and digital scale (FitScan UM-028F, Tanita Amsterdam, Netherlands), respectively. Testing session consisted of a 5 minute general warm-up, followed by 3 minutes specific warm-up consisting of heal-toe movements and jumps. After 5 minutes of rest and testing procedures explanation, subjects performed two familiarization attempts separated by 1 minute rest, and three trials of measuring the maximal plantar flexion muscle force with 2 minutes of rest between trials. ${ }^{9}$ In order to evaluate contractile characteristics of the PF, participants were positioned (see Figure 1) according to the testing procedure described by previous authors. ${ }^{10,11,12}$

\section{Variables}

Contractile characteristics (six) selected for examination in this research were:

1. Maximal isometric force $\left(\mathrm{F}_{\max }\right)$ expressed in Newtons $(\mathrm{N})$;

2. Maximal rate of the force development $\left(\mathrm{RFD}_{\max }\right)$ expressed in Newton per second $(\mathrm{N} / \mathrm{s})$, calculated as the maximum of the first one derived from the slope of the recorded F-t curve row data; ${ }^{13}$

3. Time needed to reach $F_{\text {max }}\left(\mathrm{t}_{\mathrm{m}}\right.$ max $)$, measured from the onset of contraction expressed in seconds (s);

4. Basic level of isometric rate of force development $\left(\mathrm{RFDF}_{\max }\right)$, calculated as the ratio of $F_{\text {max }}$ and $t F_{\text {max }}$ estimating the basic explosive muscle characteristics, expressed in Newton per second (N/S) ${ }^{9}$

5. Basic Synergy Index (BSI), as a criterion for evaluation of the relation between RFDF $F_{\max }$ of ankle extensors and the level of $F_{\text {max }}$ expressed in index units;

6. Specific Synergy Index (SSI), as a criterion for evaluation of the relationship between $\mathrm{RFD}_{\max }$ and the level of $\mathrm{F}_{\text {max }}$ expressed in index units. ${ }^{14}$

\section{Statistical analysis}

Statistical analyses were conducted on all 6 contractile characteristics variables obtained from three trials performed by subjects. Descriptive statistics were calculated as means and standard deviations. Prior to the

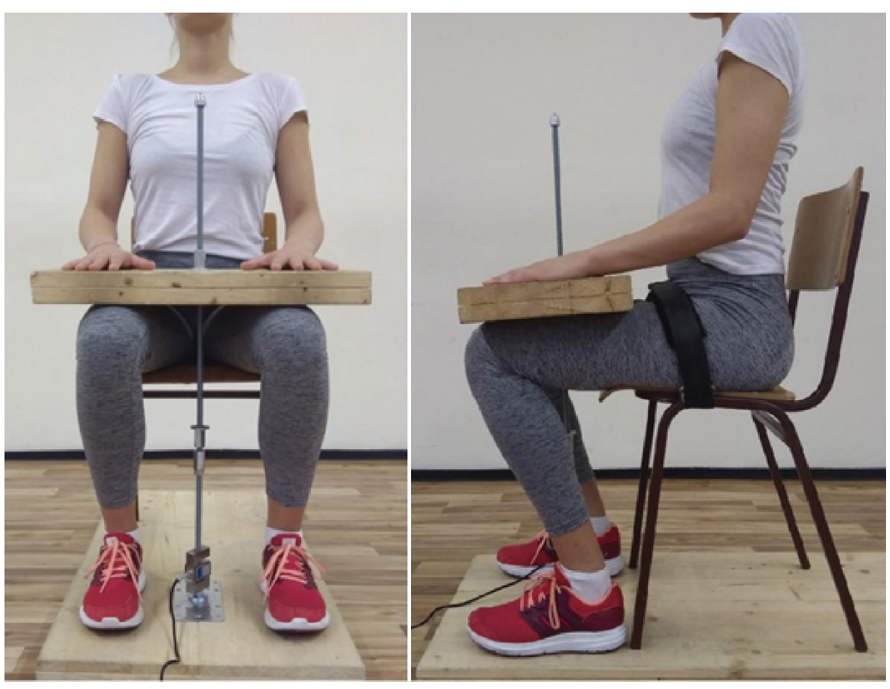

Figure 1. PF contractile characteristics measurement. 
statistical analysis, initial testing revealed that none of the variables significantly deviated from their normal distribution (Kolmogorov-Smirnov test). Repeated measures ANOVA with Bonferroni PostHoc analysis was used to evaluate the within trials differences depicted by $F$ ratio and $p$ value. Crombach's alpha coefficients of correlations were used to test the relationships between the averaged trials from all subjects, as well as Inter-Class Correlation (ICC) coefficients to test the relationships between the single trials from each subject. Principal component analysis was used to evaluate the contribution of each trial in the description of the common variability, as well as sum of squared loadings and the coefficient of cumulative variance explained by all trials. All statistical operations were carried out in the Microsoft ${ }^{\circledR}$ Office Excel 2010 (Washington, USA) and the SPSS for Windows, Release 20.0 (Copyright ${ }^{\circ}$ SPSS Inc., New York, USA).

\section{RESULTS}

Table 1 shows descriptive statistics of PF muscle contractile characteristics testing on all three trials (Mean $\pm S D$ ), with results of ANOVA (F value, and $p$ value) for assessing differences within all trials, as well as PostHoc (Bonferroni) results between individual trials. Results of ANOVA show significant differences within trials for variables $F_{\max }(F=68.498$, $\mathrm{p}=0.000)$ and $\mathrm{RFD}_{\max }(\mathrm{F}=8.513, \mathrm{p}=0.000)$ in male subjects group.

Note that the ANOVA results show that female subject group differed significantly for all variables except for the variable BSI ( $F=0.488$, $\mathrm{p}=0.594$ ). PostHoc analysis between trials in male subject group results shows significant differences between trials Trial 1 vs Trial $2(p \leq 0.05)$, and Trial 1 vs Trial $3(p \leq 0.01)$ for both $F_{\max }$ and RFD max $_{1}$ as well as Trial 2 vs Trial 3 for $F_{\max }(p \leq 0.000)$. PostHoc analysis between trials in female subject group results shows significant differences between trials Trial 1 vs Trial 2 ( $p \leq 0.05$ ) for variables: $F_{\text {max }}, R F D_{\text {max }}, \mathrm{F}_{\text {max }}, R F D F_{\text {max }}$ and Trial 1 vs Trial 3 ( $p \leq 0.01$ ) for variables: $F_{\text {max }}, R F D_{\text {max }}, R F D F_{\text {max }}, S S I$, as well as Trial 2 vs Trial 3 for variables $F_{\max }$ and $R F D_{\max }$.

Table 2 shows reliability statistical analysis with Cronbach's Alpha coefficients of correlation for averaged values of trials, as well as ICC Single measures coefficients with p values of significance for correlations between individual subject's trials. All of the Crombach's coefficients for male subjects group were between 0.680 up to 0.982, and for female subject group between 0.436 up to 0.969 (BSI and $F_{\text {max }}$ respectively) proving moderate to high correlations between averaged trials. Exceptionally high correlation coefficients $(r>0.9)$ were observed for $F_{\max }$ and $\mathrm{RFD}_{\text {max }}$ in both groups of subjects. Furthermore, ICC Single measures coefficients, ranging from 0.436 to 0.982 were significant for all of the observed variables ( $\mathrm{p} \leq 0.000)$.

Results of principal component analysis are presented in Table 3 with extracted components for each trial, followed by cumulative percentage of explained variance. The factor analysis applied on male subjects group showed that the highest common variability was generally extracted by second and third trials, where second trial had a highest value of explanation for each variable: $F_{\max }-0.988$, $\mathrm{RFD}_{\max }-0.958, \mathrm{tF}_{\max }-0.829, \mathrm{RFDF}_{\max }-0.908, \mathrm{BSI}-0.906, \mathrm{SSI}-0.848$ Female subjects group had similar results following factor analysis, with second trail explaining the highest common variability for: $F_{\max }$ - 0.982, RFD max $-0.941, \mathrm{tF}_{\text {max }}-0.786, \mathrm{RFDF}_{\text {max }}-0.786, \mathrm{SSI}-0.873$, exception being the BSI variable with third trial explaining the 0.716 of common variability. The results on the first trial in almost all of the observed variables (exception being the $\mathrm{tF}_{\max }$ in female subjects group) described the least common variability. All variables had high cumulative percentages of explained variance, with $F_{\max }$ and $R F D_{\max }$ being exceptionally high (Male: $F_{\text {max }}-96.665, R_{\text {Fax }}-88.327$; Female: $F_{\text {max }}$ - 94.221, RFD $\max -85.668$ ).

Analyzing the investigated variables average values of factor extractions, it was determined that male and female subject groups achieved values of 0.906 and 0.845 , respectively, on their second trial, while on third trial the level of extraction was 0.889 and 0.832. (Table 3) On the first trial both female and male subject had the least level of extraction values, 0.799 and 0.807 , respectively.

Table 2. Reliability analysis results.

\begin{tabular}{|c|c|c|c|c|}
\hline \multirow{2}{*}{ Gender } & \multirow{2}{*}{ Variables } & \multirow{2}{*}{$\begin{array}{c}\text { Cronbach's Alpha } \\
\text { Coeff. }\end{array}$} & \multicolumn{2}{|c|}{ ICC Single measures } \\
\hline & & & Coeff. & $p$ \\
\hline \multirow{6}{*}{ Male } & $F_{\max }(\mathrm{N})$ & 0.982 & 0.949 & 0.000 \\
\hline & $\mathrm{RFD}_{\max }(\mathrm{N} / \mathrm{s})$ & 0.933 & 0.822 & 0.000 \\
\hline & $\mathrm{tF}_{\max }(\mathrm{s})$ & 0.765 & 0.521 & 0.000 \\
\hline & $\mathrm{RFDF}_{\max }(\mathrm{N} / \mathrm{s})$ & 0.770 & 0.527 & 0.000 \\
\hline & BSI (Indx. Un) & 0.680 & 0.415 & 0.000 \\
\hline & SSI (Indx. Un) & 0.776 & 0.536 & 0.000 \\
\hline \multirow{6}{*}{ Female } & $F_{\max }(\mathrm{N})$ & 0.969 & 0.912 & 0.000 \\
\hline & $\mathrm{RFD}_{\max }(\mathrm{N} / \mathrm{s})$ & 0.916 & 0.785 & 0.000 \\
\hline & $\mathrm{tF}_{\max }(\mathrm{s})$ & 0.657 & 0.390 & 0.000 \\
\hline & $\mathrm{RFDF}_{\max }(\mathrm{N} / \mathrm{s})$ & 0.644 & 0.376 & 0.000 \\
\hline & BSI (Indx. Un) & 0.436 & 0.205 & 0.000 \\
\hline & SSI (Indx. Un) & 0.791 & 0.557 & 0.000 \\
\hline
\end{tabular}

Table 1. Basic descriptive statistics with ANOVA and Post Hoc differences results between trials.

\begin{tabular}{|c|c|c|c|c|c|c|}
\hline \multirow{2}{*}{ Gender } & \multirow{2}{*}{ Variables } & \multicolumn{3}{|c|}{ Testing trial (mean \pm st dev.) } & \multicolumn{2}{|c|}{ ANOVA } \\
\hline & & Trial 1 & Trial 2 & Trial 3 & $\mathrm{~F}$ & $p$ \\
\hline \multirow{5}{*}{ Male } & $\mathrm{F}_{\text {max }}(\mathrm{N})$ & $3111.4 \pm 900.9$ & $3276.4 \pm 915.3^{* * *}$ & $3415.1 \pm 858.6^{\# \# \#++\dagger}$ & 68.498 & 0.000 \\
\hline & $\mathrm{RFD}_{\max }(\mathrm{N} / \mathrm{s})$ & $14515.8 \pm 4566.2$ & $15162.4 \pm 4249.2^{*}$ & $15477.7 \pm 4280.2^{\# \#}$ & 8.513 & 0.000 \\
\hline & $\mathrm{tF}_{\text {max }}(\mathrm{s})$ & $1.078 \pm 0.462$ & $1.125 \pm 0.521$ & $1.114 \pm 0.472$ & 0.635 & 0.519 \\
\hline & $\mathrm{RFDF}_{\max }(\mathrm{N} / \mathrm{s})$ & $3628.8 \pm 2445.1$ & $3534.1 \pm 1853.1$ & $3696.6 \pm 1952.2$ & 0.383 & 0.628 \\
\hline & BSI (Indx. Un) & $1.207 \pm 0.856$ & $1.108 \pm 0.563$ & $1.096 \pm 0.568$ & 0.716 & 0.423 \\
\hline \multirow{5}{*}{ Female } & $F_{\max }(N)$ & $2359.2 \pm 581.3$ & $2553.6 \pm 613^{* * *}$ & $2664.0 \pm 627.1^{\# \# \#++\dagger}$ & 244.343 & 0.000 \\
\hline & $\mathrm{RFD}_{\max }(\mathrm{N} / \mathrm{s})$ & $11410.9 \pm 3245$ & $12148.4 \pm 3313.4^{* * *}$ & $12507.9 \pm 3364.4^{\# \# \#+\dagger}$ & 44.105 & 0.000 \\
\hline & $\mathrm{tF}_{\max }(\mathrm{s})$ & $1.00 \pm 0.428$ & $0.93 \pm 0.405^{*}$ & $0.954 \pm 0.419$ & 3.874 & 0.021 \\
\hline & $\mathrm{RFDF}_{\max }(\mathrm{N} / \mathrm{s})$ & $2923.2 \pm 1680.5$ & $3281.4 \pm 1534.9^{* *}$ & $3328.8 \pm 1553.9^{\# \# \#}$ & 10.334 & 0.000 \\
\hline & BSI (Indx. Un) & $1.269 \pm 0.846$ & $1.3 \pm 0.594$ & $1.255 \pm 0.532$ & 0.488 & 0.594 \\
\hline
\end{tabular}

Trial 1 vs Trial $2:{ }^{*}=p \leq 0.050,{ }^{* *}=p \leq 0.010,{ }^{* * *}=p \leq 0.000 ;$ Trial 1 vs Trial 3: $\#=p \leq 0.050, \# \#=p \leq 0.010, \# \# \#=p \leq 0.000 ;$ Trial 2 vs Trial 3: $\dagger=p \leq 0.050$, $+\dagger=p \leq 0.010,+\dagger+=p \leq 0.000$; 
Table 3. Principal Component analysis results.

\begin{tabular}{|c|c|c|c|c|c|c|c|c|}
\hline \multirow{2}{*}{ Gender } & \multirow{2}{*}{ Trials } & \multicolumn{6}{|c|}{ Variables } & \multirow[b]{2}{*}{ Average } \\
\hline & & $\mathrm{F}_{\max }(\mathrm{N})$ & $\mathrm{RFD}_{\max }(\mathrm{N} / \mathrm{s})$ & $\mathrm{tF}_{\max }(\mathrm{s})$ & $\mathrm{RFDF}_{\max }(\mathrm{N} / \mathrm{s})$ & BSI (Indx. Un) & SSI (Indx. Un) & \\
\hline \multirow{4}{*}{ Male } & Trial 1 & 0.980 & 0.924 & 0.703 & 0.748 & 0.618 & 0.821 & 0.799 \\
\hline & Trial 2 & 0.988 & 0.958 & 0.829 & 0.908 & 0.906 & 0.848 & 0.906 \\
\hline & Trial 3 & 0.982 & 0.937 & 0.826 & 0.858 & 0.885 & 0.848 & 0.889 \\
\hline & Variance Explained & 96.665 & 88.327 & 62.095 & 70.603 & 66.218 & 70.416 & 75.721 \\
\hline \multirow{4}{*}{ Female } & Test 1 & 0.961 & 0.908 & 0.769 & 0.734 & 0.661 & 0.806 & 0.807 \\
\hline & Test 2 & 0.982 & 0.941 & 0.786 & 0.786 & 0.704 & 0.873 & 0.845 \\
\hline & Test 3 & 0.969 & 0.928 & 0.741 & 0.775 & 0.716 & 0.863 & 0.832 \\
\hline & Variance Explained & 94.221 & 85.668 & 58.573 & 58.571 & 48.191 & 71.812 & 69.506 \\
\hline
\end{tabular}

\section{DISCUSSION}

The main findings of this research were that trials differed significantly, indicating that the procedural three trials are needed to assess the subjects PF contractile characteristics. Furthermore, test trials correlated highly proving that measurement was reliable, and factorial analysis depicted second and third, where second trial was the one describing the most of the common variability, although results on the third trial were usually the highest. (Table 1 and 3)

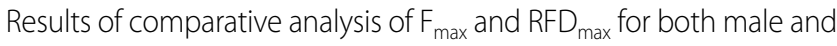
female subject groups indicated significant differences between trials. ${ }^{15}$ This research has shown that the best $F_{\text {max }}$ results in absolute terms were achieved in Trial 3 for both male and female subjects group. (Table 1) Observing the PF muscles, it can be argued that the index of gender dimorphism, i.e. the average measured value of female $F_{\max }$ is on the level of $78.01 \%$ in relation to male subjects, meaning that the female subjects had $21.99 \%$ lower level of maximally achieved voluntary force. Observing the RFD $\max$ absolute values on three trials, the highest values were also achieved in Trial 3. (Table 1) Gender dimorphism index showed that the female subjects group had 19.19\% lower plantar flexors maximal explosiveness compared to male group. These findings are in line with previous research, indicating greater capacities for force production in male subjects, given their higher percentages of muscle mass. ${ }^{16-18}$ Results of ANOVA for variables: $\mathrm{tF}_{\text {max }}$ $\mathrm{RFDF}_{\max } \mathrm{BSI}$, and SSI, evaluating contractile characteristics of muscles, didn't show any differences observing male subjects group which is also comparable to previous studies. ${ }^{12}$ However, results of female subject group showed significant differences within trials, which could be explained by differences observed in $\mathrm{tF}_{\text {max }}$ given that it affects all following variables.

Interestingly $\mathrm{tF}_{\text {max }}$ results show some inconsistencies for different gender groups of subjects, while male subjects group average $\mathrm{F}_{\text {max }}$ was the fastest in Trial 1, followed by Trial 3, and then Trial 2 as the slowest, female subject group's order of trials was exact opposite to males, with Trial 2 being the fastest, followed by Trial 3, and Trial 1. Male subjects group Trial 1 results of $F_{\text {max }}$ can present a good explanation to these $\mathrm{t}_{\text {max }}$ inconsistencies over trials, given that it was on significantly lower level compared to other two trials $(3111.4 \pm 900.9 \mathrm{~N}, \mathrm{p}=0.000)$, so it was expected that the time needed to reach this level of force would be faster compared to Trial 2 , and Trial 3 with larger $F_{\text {max }} \cdot{ }^{19}$ In comparison to results of female subjects group, previous researchers also found diversity of $\mathrm{tF}_{\text {max }}$ over trials, Dopsaj \& Ivanovic ${ }^{9}$ even added a Trial 4, and still couldn't conclude any regularity over trials. Basic explosive muscle characteristic described by RFDF max $_{\text {ax }}$ is highly dependable on $\mathrm{tF}_{\text {max' }}$ so the results of male subjects over trials were inconsistent as expected, while female group on the other hand had a stabile rising trend. Male RFDF ${ }_{\text {max }}$ results were highest on the Trial 3, followed by Trial 1, and then Trial 2, explained by the fact that second trial had a moderate level of $F_{\text {max }}$, but achieved it with the slowest $\mathrm{tF}_{\text {max }}$ so the resulting RFDF $_{\max }$ was only $3534.1 \pm 1853.1 \mathrm{~N} / \mathrm{s}$. (Table 1)

Results of BSI of plantar flexor muscles proved to be higher compared to previous studies including leg press isometric force production, 12,14 which could be explained by lower RFDF max $_{\text {mat }}$ observed in this study. These findings were expected because of the testing procedure, including a single joint muscle force production compared to multi joint used in previous studies. SSI for both gender groups declined through trials because the rise of $F_{\max }$ wasn't matched by appropriate rise in $R F D_{\max }$. These findings suggest that when examining results on Trial 1, the subject was much further from expressing his potentials for maximal force production, and on the other hand closer to expressing potentials for rapid force production.

PostHoc analysis depicted the third measurement trial as statistically higher compared to first two for variables $F_{\max }$ and RFD max in both groups, with female groups' third trial also being the highest for other variables: $\mathrm{tF}_{\text {max }}, \mathrm{RFDF}_{\text {max }}$ and $\mathrm{SSI}$. Based on this robust set of data one could generally conclude that the measurement procedure including three trials, is needed to estimate the $F_{\max }$ and $\mathrm{RFD}_{\text {max }}$ as well as the other contractile characteristics of plantar flexor muscles, ${ }^{9}$ with third trial most likely to show the highest results. Reliability analysis showed that correlations between trials were exceptionally strong, (Table 2) with coefficients ranging from 0.436 to 0.982 ( $p \leq 0.000$ ), comparable to previous researches conducted in laboratory conditions, ${ }^{20}$ if not even stronger compared to hand-held dynamometry, 5,21 This was expected, given that the conditions and procedure settings were notably more controlled then the ones in hand-held dynamometry. ${ }^{22,23}$

Results of this study revealed that, besides $F_{\text {max }}$ contractile characteristics described trough variables: $\mathrm{RFD}_{\text {max }}, \mathrm{tF}_{\text {max }}, \mathrm{RFDF}_{\text {max }} \mathrm{BSI}$ and $\mathrm{SSI}$ were also best described in trials two and three. (Table 3 ) In literature, differences in number of trials range from three, ${ }^{19}$ or four, ${ }^{9}$ to five, ${ }^{12}$ with our research compromising this matter by involving two practice attempts followed by three measurement trials with one of the two last trials being the most representative of the subjects PF muscle contractile characteristics.

\section{CONCLUSIONS}

The simple novel field test for measurement of plantar flexor contractile characteristics recommended by this study proved to be as highly reliable as laboratory testing but being easy to perform in conditions outside of scientific or diagnostic institutions. The variables were all found to be highly statistically reliable $(p=0.000)$, with $F_{\max }$ and $R F D_{\max }$ having the highest coefficients of reliability, ranging from 0.916 to 0.982 , followed by $\mathrm{tF}_{\text {max }}$ $\mathrm{RFDF}_{\text {max }}$ and SSI, from 0.644 to 0.791 , and BSI with the reliability at the level of 0.436 to 0.680 , regardless of the gender. According to the results of this study, we can recommend the same procedure for both genders, including two familiarization attempts followed by three measurement trials, after which the trial taken into consideration would be the higher of the last two. This testing procedure could enable sport scientist, as well as coaches or athletes themselves to monitor the conditioning, and contractile state of one of the most important muscle groups involved in almost all dynamic lover body part movements, as well as static positions during everyday or specific sport situations. This procedure would also help clinicians with 
the simple solution to follow the rehabilitation of individuals, which had injuries making it hard for them to leave the rehabilitation facilities. Future research should investigate the tests concurrent validity, comparing it to the other "golden standard"tests, it should examine the day-to-day reliability of the procedure, as well as the sensitivity with different age groups and differently trained groups of subjects.

\section{ACKNOWLEDGMENT}

The study was partly supported by the grant III47015 of the Research Council of the Republic of Serbia.

All authors declare no potential conflict of interest related to this article

AUTHORS' CONTRIBUTIONS: Each author made significant individual contributions to this manuscript. NM: was the main contributor to the drafting of the manuscript, performed all assessments described in Methods, and participated in the entire scientific research process; GN: writing and revision, and intellectual concept. VG: statistical analysis, measurement and revision; ZS: statistical analysis, measurement and revision; MŽ: writing, revision and intellectual concept; ZA: statistical analysis, measurement; SM: statistical analysis, measurement; MD: writing, revision and intellectual concept.

\section{REFERENCES}

1. Ema R, Saito M, Ohki S, Takayama H, Yamada Y, Akagi R. Association between rapid force production by the plantar flexors and balance performance in elderly men and women. Age (Dordr). 2016;38(5-6):475-83.

2. Ruiz-Cárdenas JD, Rodríguez-Juan JJ, Ríos-Díaz J. Relationship between jumping abilities and skeletal muscle architecture of lower limbs in humans: Systematic review and meta-analysis. Hum Mov Sci. 2018;58:10-20.

3. Ribas LO, Schedler FB, Pacheco I, Pacheco AM. Proprioception and Muscle Strengthening in the Stability of the Ankle in Female Indoor Soccer Athletes. Rev Bras Med Esporte. 2017;23(5):412-7.

4. Maffiuletti NA, Pensini M, Martin A. Activation of human plantar flexor muscles increases after electromyostimulation training. J Appl Physiol (1985). 2002;92(4):1383-92.

5. Mentiplay BF, Perraton LG, Bower KJ, Adair B, Pua YH, Williams GP, et al. Assessment of lower limb muscle strength and power using hand-held and fixed dynamometry: A reliability and validity study. PLoS One. 2015;10(10):e0140822.

6. Topalidou A, Tzagarakis G, Souvatzis $X$, Kontakis $G$, Katonis $P$. Evaluation of the reliability of a new non-invasive method for assessing the functionality and mobility of the spine. Acta Bioeng Biomech. 2014;16(1):117-24.

7. Andrade RM, Figueira Júnior AJ, Metz V, Amadio AC, Serrão JC. Interpretation of propulsive force in tethered swimming through principal component analysis. Rev Bras Med Esporte. 2018;24(3):178-81.

8. Takahashi M, Koide K, Suzuki H, Satoh Y, Iwasaki SI. Evaluation of reliability of perioral muscle pressure measurements using a newly developed device with a lip piece. Acta Bioeng Biomech. 2016;18(1):145-53.

9. Dopsaj M, Ivanović J. The analysis of the reliability and factorial validity in the basic characteristics of isometric Ft curve of the leg extensors in well trained serbian males and females. Meas Sci Rev. 2011;11(5):165-72.

10. Majstorović N, Dopsaj M, Grbic V, Savic Z, Vicentijevic A, Anicic Z, et al. Isometric strength in volleyball players of different age: A multidimensional model. Applied Sciences. 2020;10(12):4107-19.

11. Mirkov DM, Knezevic OM, Maffiuletti NA, Kadija M, Nedeljkovic A, Jaric S. Contralateral limb deficit after ACL-reconstruction: an analysis of early and late phase of rate of force development. J Sports Sci. 2017;35(5):435-40.
12. Ivanović J, Dopsaj M. Reliability of force-time curve characteristics during maximal isometric leg press in differently trained high-level athletes. Measurement. 2013;46(7):2146-54.

13. Sahaly R, Vandewalle H, Driss T, Monod H. Maximal voluntary force and rate of force development in humans-importance of instruction. Eur J Appl Physiol. 2001;85(3-4):345-50.

14. Mirkov DM, Nedeljkovic A, Milanovic S, Jaric S. Muscle strength testing: evaluation of tests of explosive force production. Eur J Appl Physiol. 2004;91(2-3):147-54.

15. Reinking MF, Bockrath-Pugliese K, Worrell T, Kegerreis RL, Miller-Sayers K, Farr J. Assessment of quadriceps muscle performance by hand-held, isometric, and isokinetic dynamometry in patients with knee dysfunction. J Orthop Sports Phys Ther. 1996;24(3):154-9.

16. Fukunaga T, Miyatani M, Tachi M, Kouzaki M, KawakamiY, Kanehisa H. Muscle volume is a major determinant of joint torque in humans. Acta Physiol Scand. 2001;172(4):249-55.

17. Akagi R, TakaiY, Ohta M, Kanehisa H, Kawakami Y, Fukunaga T. Muscle volume compared to cross-sectiona area is more appropriate for evaluating muscle strength in young and elderly individuals. Age Ageing. 2009;38(5):564-9.

18. Ivanović J, Dopsaj M. Functional dimorphism and characteristics of maximal hand grip force in top level female athletes. Collegium Antropologicum. 2012;36(4):1231-40.

19. Demura S, Yamaji S, Nagasawa Y, Sato S, Minami M, Yoshimura Y. Reliability and gender differences of static explosive grip parameters based on force-time curves. J Sports Med Phys Fitness. 2003;43(1):28-35.

20. Kawamori N, Haff GG. The optimal training load for the development of muscular power. J Strength Cond Res. 2004;18(3):675-84.

21. André HI, Carnide F, Borja E, Ramalho F, Santos-Rocha R, Veloso AP. Calf-raise senior: a new test for assessment of plantar flexor muscle strength in older adults: protocol, validity, and reliability. Clin Interv Aging. 2016;11:1661-74.

22. Wang CY, Olson SL, Protas EJ. Test-retest strength reliability: hand-held dynamometry in communitydwelling elderly fallers. Arch Phys Med Rehabil. 2002;83(6):811-5.

23. Sleivert GG, Wenger HA. Reliability of measuring isometric and isokinetic peak torque, rate of torque development, integrated electromyography, and tibial nerve conduction velocity. Arch Phys Med Rehabil. 1994;75(12):1315-21 